\title{
Effects of sex on characteristics and expression levels of digestive enzymes in the adult guppy Poecilia reticulata
}

Karun Thongprajukaew ${ }^{1,2^{*}}$ and Uthaiwan Kovitvadhi ${ }^{2,3}$

\begin{abstract}
Background: Characteristics ( $\mathrm{pH} 2$ to 12 and temperature of $25^{\circ} \mathrm{C}$ to $80^{\circ} \mathrm{C}$ ) and expression levels of the main digestive enzymes, including amylase, lipase, total protease, trypsin, and chymotrypsin, were investigated in adult male and female guppies Poecilia reticulata. A completely randomized design was used during this experiment.

Results: Digestive enzyme studies indicated that sex had a direct effect on characteristic profiles $(n=3)$ and expression levels ( $n=10$ ) of all digestive enzymes. The most suitable conditions for studying digestive enzymes in general were $\mathrm{pH} 2$ at $50^{\circ} \mathrm{C}$ for acidic amylase, $\mathrm{pH} 7$ at $55^{\circ} \mathrm{C}$ for neutral amylase, $\mathrm{pH} 11$ at $50^{\circ} \mathrm{C}$ for alkaline amylase, $\mathrm{pH} 7$ at $30^{\circ} \mathrm{C}$ to $35^{\circ} \mathrm{C}$ for lipase, $\mathrm{pH} 2$ at $55^{\circ} \mathrm{C}$ for acidic protease, $\mathrm{pH} 9$ at $45^{\circ} \mathrm{C}$ for alkaline protease, $\mathrm{pH} 8$ at $50^{\circ} \mathrm{C}$ for trypsin, and $\mathrm{pH} 9$ at $50^{\circ} \mathrm{C}$ for chymotrypsin, regardless of sex. Specific activities of amylase, total protease, trypsin, and chymotrypsin were higher in females than males $(p<0.001$ ), while the specific activity of lipase was higher in males than females. These findings were correlated with the higher growth capacity of females than males (except for lipase), as indicated by differences in body weight $(p<0.001)$, length $(p<0.001)$, and the activity ratio of trypsin (T) to chymotrypsin (C), i.e., the $T / C$ ratio $(p<0.007)$.
\end{abstract}

Conclusions: Feeding habits of adult guppies differed between sexes, as indicated by a difference in the activity ratio between amylase and trypsin, i.e., the $A / T$ ratio $(p<0.04)$. Information from digestive enzyme studies, as well as using optimal conditions of digestive enzymes to study in vitro nutrient utilization in guppies, might be important to understand the effects of sex on nutritional responses.

Keywords: Characteristics; Digestive enzymes; Guppy; Poecilia reticulata; Sex

\section{Background}

The guppy Poecilia reticulata is a small, beautiful, peaceful, lively, hardy fish. It is a popular freshwater aquarium fish around the world. Many strains of guppies have been created based on body color, color patterns, and fin shape (Nakajima and Taniguchi 2002). Moreover, in the same strain, differences in morphological appearances between sexes can clearly be observed, as female bodies are larger and rounder than those of males, while male fins are more colorful and larger than those of females. Recently, studies on digestive enzyme characteristics in

\footnotetext{
* Correspondence: karun.t@psu.ac.th

${ }^{1}$ Department of Applied Science, Faculty of Science, Prince of Songkla University, Songkhla 90112, Thailand

${ }^{2}$ Biochemical Research Unit for Feed Utilization Assessment, Faculty of Science, Kasetsart University, Bangkok 10900, Thailand

Full list of author information is available at the end of the article
}

Siamese fighting fish Betta splendens indicated that female fish probably developed earlier than male fish when fed the same diet (Thongprajukaew et al. 2010a, b). This evidence led us to examine digestive enzymes as key markers of sexual dimorphism in that species (Thongprajukaew et al. 2013). A similar emphasis of sex on digestive enzymes was also found in the freshwater pearl mussel Hyriopsis (Hyriopsis) bialatus with the possibility of improving diet formulations (Areekijseree et al. 2004). These results indicated that differences in digestive strategies of nutrient utilization can be influenced by sex.

Utilization of nutrients in aquatic animals depends on the activity of their digestive enzymes (Areekijseree et al. 2006; Rungruangsak-Torrissen et al. 2006; Supannapong et al. 2008). Moreover, the digestive organ mass of fish positively contributes to the growth capacity (Thongprajukaew et al. 2011) by increasing the efficiencies of digestion, 
absorption, and utilization of nutrients. The use of digestive enzyme information for in vitro screening of feed ingredients was investigated in the freshwater pearl mussel (Areekijseree et al. 2006, Supannapong et al. 2008), spiny lobster Panulirus argus (Perera et al. 2010), and Siamese fighting fish (Thongprajukaew et al. 2013). Moreover, digestive enzyme activity was also used to determine growth (Sunde et al. 2001; Rungruangsak-Torrissen et al. 2006; Rungruangsak-Torrissen 2007; Thongprajukaew et al. 2011) and optimal feeding management (Chan et al. 2008; Xie et al. 2011).

Therefore, information on digestive enzymes can provide elementary knowledge to help understand the nutritional status of an aquatic animal. The objective of this study was to investigate the effect of sex on characteristics and expression levels of the main digestive enzymes including amylase, lipase, and proteolytic enzymes (total proteases, trypsin, and chymotrypsin) in the digestive tract of guppies. Information from this study may be important in determining future in vitro nutrient utilization of sex-specific feed formulations by guppies.

\section{Methods}

Fish culture and sample collection

Four-month-old male and female guppies were obtained from a private farm in Nakhon Pathom Province, Thailand. Fish sex was identified by morphological differences including body weight (BW), total length (TL), and color intensity. Fish were acclimatized in an aquarium $(18-\mathrm{cm}$ wide $\times 34-\mathrm{cm}$ long $\times 19-\mathrm{cm}$ high) with a $15-\mathrm{cm}$ water level for 14 days. During acclimatization, fish were fed $a d$ libitum, twice daily (at 0800 hours and 1700 hours), with a commercial diet for herbivorous fish containing $32 \%$ protein, $4 \%$ lipids, $5 \%$ fiber, and $10 \%$ ash. Seventy-five percent of the water content was changed every other day. Water quality measurements included temperature of $28.32^{\circ} \mathrm{C} \pm 0.05^{\circ} \mathrm{C}, \mathrm{pH} 7.51 \pm 0.03$, and dissolved oxygen of $7.44 \pm 0.04 \mathrm{mg} / \mathrm{l}$. At the end of acclimatization, the fish were starved for $24 \mathrm{~h}$ prior to sampling to avoid the effect of diet ingestion on digestive enzyme activities. Fish were sacrificed by chilling in ice according to the Ethical Principles and Guidelines for the Use of Animals for Scientific Purposes of the National Research Council, Thailand. BW and TL were individually measured before carefully collecting the digestive organs and the carcass. All tissues were then stored at $-80^{\circ} \mathrm{C}$ until being analyzed.

\section{Digestive enzyme studies}

\section{Digestive enzyme extraction}

Digestive enzymes from male and female guppies were extracted from whole digestive organs using a microhomogenizer (THP-220; Omni International, Kennesaw, GA, USA) in the presence of $50 \mathrm{mM}$ Tris- $\mathrm{HCl}$ buffer $(\mathrm{pH})$ containing $200 \mathrm{mM} \mathrm{NaCl}(1: 3 w / v)$. The homogenate was centrifuged at $15,000 \times g$ for $30 \mathrm{~min}$ at $4^{\circ} \mathrm{C}$. The lipid portion on the upper layer of the supernatant was carefully removed. The supernatant was collected and then kept at $-80^{\circ} \mathrm{C}$ until the digestive enzyme assays were run. The protein concentration in the enzyme extract was determined according to Lowry et al. (1951) using bovine serum albumin as a standard curve.

\section{Characterization and specific activities of digestive enzymes}

$\mathrm{pH}$ and temperature characteristics of the main digestive enzymes were assayed according to the method described by Thongprajukaew et al. (2010a, b). Data for digestive enzyme assays are summarized in Table 1. $\mathrm{pH}$ profiles were studied at an ambient temperature using the following buffers: glycine- $\mathrm{HCl}$ for $\mathrm{pH} \mathrm{2}$, citrate-phosphate buffer for $\mathrm{pH} 3$ to 5, phosphate buffer for $\mathrm{pH} 6$ to $8, \mathrm{NaHCO}_{3}$ $\mathrm{Na}_{2} \mathrm{CO}_{3}$ buffer for $\mathrm{pH} 9$ to $10, \mathrm{Na}_{2} \mathrm{HPO}_{4}-\mathrm{NaOH}$ for $\mathrm{pH}$ 11 , and $\mathrm{KCl}-\mathrm{NaOH}$ for $\mathrm{pH}$ 12. Temperature profiles $\left(25^{\circ} \mathrm{C}\right.$ to $\left.80^{\circ} \mathrm{C}\right)$ were determined at optimal $\mathrm{pH}$ values. For specific activities, all digestive enzymes were assayed at specified optimal conditions, as described in Table 2. The specific activities of digestive enzymes are expressed in units per milligram of protein with 1 unit of enzymes defined as $1 \mu \mathrm{mol}$ of substrate released per minute. For total protease, the unit of enzyme activity was defined as the amount of enzyme causing an increase of 1.0 absorbance unit at $440 \mathrm{~nm}$.

\section{Determination of body compositions}

Moisture and ash were respectively determined using an automatic moisture analyzer balance (MA 30; Sartorius, Göttingen, Germany) and a muffle furnace (ELF 11/14; Carbolite Limited, Hope Valley, UK), according to AOAC (2005). Protein concentrations were determined using TRIzol $^{\circledR}$ reagent (Invitrogen, Carlsbad, CA, USA), as described in Rungruangsak-Torrissen (2007). The extinction coefficient for calculating protein concentrations was $E_{280}=2.1 \mathrm{mg} / \mathrm{ml}$. Lipid contents were extracted using ethyl acetate, as described by Supannapong et al. (2008). All values were expressed on a wet weight basis.

\section{Statistical analysis and calculations}

The experiment was performed with a completely randomized design. Seventy fish of each sex $(n=70)$ were divided into three pooled samples ( $n=3$ from 60 fish) to characterize digestive enzymes, and ten fish $(n=10)$ were used to study body compositions and specific activities of digestive enzymes. All data are expressed as the mean \pm standard error of the mean. Significant differences between sexes were compared using an independent-sample $t$ test. A condition factor $\left(\mathrm{CF}, \mathrm{g} / \mathrm{cm}^{3}\right)$ and digestosomatic index (DSI, \%) were calculated from the respective equations, $100 \times\left(\right.$ live $\mathrm{BW} / \mathrm{TL}^{3}$ ) and $100 \times$ (digestive tract weight/ BW), as described by Thongprajukaew et al. (2011). 
Table 1 Digestive enzyme assays used in the experiment

\begin{tabular}{lll}
\hline Digestive enzyme & Substrate & Reference \\
\hline a-Amylase (EC 3.2.1.1) & Soluble starch & Areekijseree et al. (2004) \\
Lipase (EC 3.1.1.3) & $p$-Nitrophenyl palmitate & Winkler and Stuckmann (1979) \\
Total proteases & Azocasein & Areekijseree et al. (2004) \\
Trypsin (EC 3.4.21.4) & $n$-Benzoyl-L-arginine-p-nitroanilide & Rungruangsak-Torrissen et al. (2006) \\
Chymotrypsin (EC 3.4.21.1) & $n$-Succinyl-ala-ala-pro-phenylalanine-p-nitroanilide & Rungruangsak-Torrissen et al. (2006) \\
\hline
\end{tabular}

\section{Results}

\section{Effects of sex on growth indicators and body compositions}

Significant differences in growth indicators were observed between sexes. Females had a higher BW $(p<0.001$, Table 2$)$, TL $(p<0.001)$, and CF $(p<0.001)$ than males by 2.54-, 1.26-, and 1.27-fold, respectively. The gastrointestinal weight of females was significantly higher than that of males $(p<0.001)$, by approximately 2.23 -fold. However, the DSI did not differ between sexes $(p>0.05)$. As to body compositions, moisture and lipids significantly differed between sexes $(p<0.003$, Table 2$)$. Females had a higher lipid content than males, while protein and ash did not differ between sexes $(p>0.05)$.

\section{Effects of sex on digestive enzyme characteristics Characterization of amylase}

Male and female guppies showed similar amylase characteristics at various $\mathrm{pH}$ values (Figure 1a). Optimal conditions for studying amylase in a neutral to alkaline solution ranged from $\mathrm{pH} 7$ to 9, while extremely acidic and alkaline solutions were pH 2 and 11, respectively (Figure 1a). Optimal

Table 2 Growth parameters, body compositions, and digestive enzyme-specific activities of adult male and female guppies

\begin{tabular}{|c|c|c|c|}
\hline Parameter & Male & Female & $p$ value \\
\hline Body weight (g), $n=70$ & $0.35 \pm 0.01$ & $0.89 \pm 0.02$ & $<0.001^{c}$ \\
\hline Total length $(\mathrm{cm}), n=70$ & $3.40 \pm 0.02$ & $4.27 \pm 0.03$ & $<0.001^{c}$ \\
\hline Condition factor $\left(\mathrm{g} / \mathrm{cm}^{3}\right), n=70$ & $0.89 \pm 0.02$ & $1.13 \pm 0.01$ & $<0.001^{c}$ \\
\hline \multicolumn{4}{|l|}{ Digestive index, $n=70$} \\
\hline 1. Gastrointestinal weight (g) & $0.030 \pm 0.01$ & $0.067 \pm 0.007$ & $<0.001^{c}$ \\
\hline 2. Digestosomatic index (\%) & $9.02 \pm 0.60$ & $8.99 \pm 0.65$ & 0.961 \\
\hline \multicolumn{4}{|l|}{ Body composition (\%), $n=10$} \\
\hline 1. Moisture & $76.82 \pm 0.32$ & $75.14 \pm 0.19$ & $0.002^{c}$ \\
\hline 2. Lipids & $2.69 \pm 0.09$ & $3.16 \pm 0.08$ & $0.002^{c}$ \\
\hline 3. Protein & $13.76 \pm 0.59$ & $11.47 \pm 0.54$ & 0.430 \\
\hline 4. Ash & $3.42 \pm 0.08$ & $3.69 \pm 0.19$ & 0.195 \\
\hline \multicolumn{4}{|l|}{ Digestive enzymes, $n=10$} \\
\hline \multicolumn{4}{|l|}{ 1. Amylase $(A)^{a}$} \\
\hline 1.1 Acidic amylase $\left(\mathrm{pH} 2,50^{\circ} \mathrm{C}\right)$ & $16.26 \pm 0.58$ & $39.51 \pm 1.25$ & $<0.001^{\mathrm{c}}$ \\
\hline 1.2 Neutral amylase $\left(\mathrm{pH} 7,55^{\circ} \mathrm{C}\right)$ & $17.40 \pm 1.17$ & $36.86 \pm 1.33$ & $<0.001^{c}$ \\
\hline 1.3 Alkaline amylase $\left(\mathrm{pH} 11,50^{\circ} \mathrm{C}\right)$ & $16.39 \pm 0.74$ & $37.95 \pm 0.95$ & $<0.001^{c}$ \\
\hline 2. Neutral lipase $\left(\mathrm{pH} 7,35^{\circ} \mathrm{C}\right)^{\mathrm{a}}$ & $1.04 \pm 0.09$ & $0.42 \pm 0.02$ & $<0.001^{c}$ \\
\hline \multicolumn{4}{|l|}{ 3. Total proteases ${ }^{\mathrm{b}}$} \\
\hline 3.1 Acidic protease $\left(\mathrm{pH} 2,55^{\circ} \mathrm{C}\right)$ & $111.69 \pm 7.68$ & $244.07 \pm 7.23$ & $<0.001^{\mathrm{C}}$ \\
\hline 3.2 Alkaline protease $\left(\mathrm{pH} 9,45^{\circ} \mathrm{C}\right)$ & $74.70 \pm 7.11$ & $231.91 \pm 18.94$ & $<0.001^{c}$ \\
\hline 4. Trypsin (T) $\left(\mathrm{pH} 8,50^{\circ} \mathrm{C}\right)^{\mathrm{a}}$ & $0.61 \pm 0.03$ & $2.06 \pm 0.19$ & $<0.001^{\mathrm{c}}$ \\
\hline 5. Chymotrypsin (C) $\left(\mathrm{pH} 9,50^{\circ} \mathrm{C}\right)^{\mathrm{a}}$ & $0.20 \pm 0.01$ & $0.38 \pm 0.01$ & $<0.001^{c}$ \\
\hline 6. $\mathrm{T} / \mathrm{C}$ ratio & $3.07 \pm 0.05$ & $5.39 \pm 0.44$ & $0.006^{c}$ \\
\hline 7. $\mathrm{A} / \mathrm{T}$ ratio & $30.29 \pm 2.35$ & $22.88 \pm 0.26$ & $0.035^{c}$ \\
\hline
\end{tabular}

${ }^{\mathrm{a}}$ Expressed in units per milligram $(\mathrm{U} / \mathrm{mg})$ of protein. ${ }^{\mathrm{b}}$ Expressed in milliunits per milligram $(\mathrm{mU} / \mathrm{mg})$ of protein. ${ }^{c}$ Differed significantly $(p<0.05)$ between sexes. 


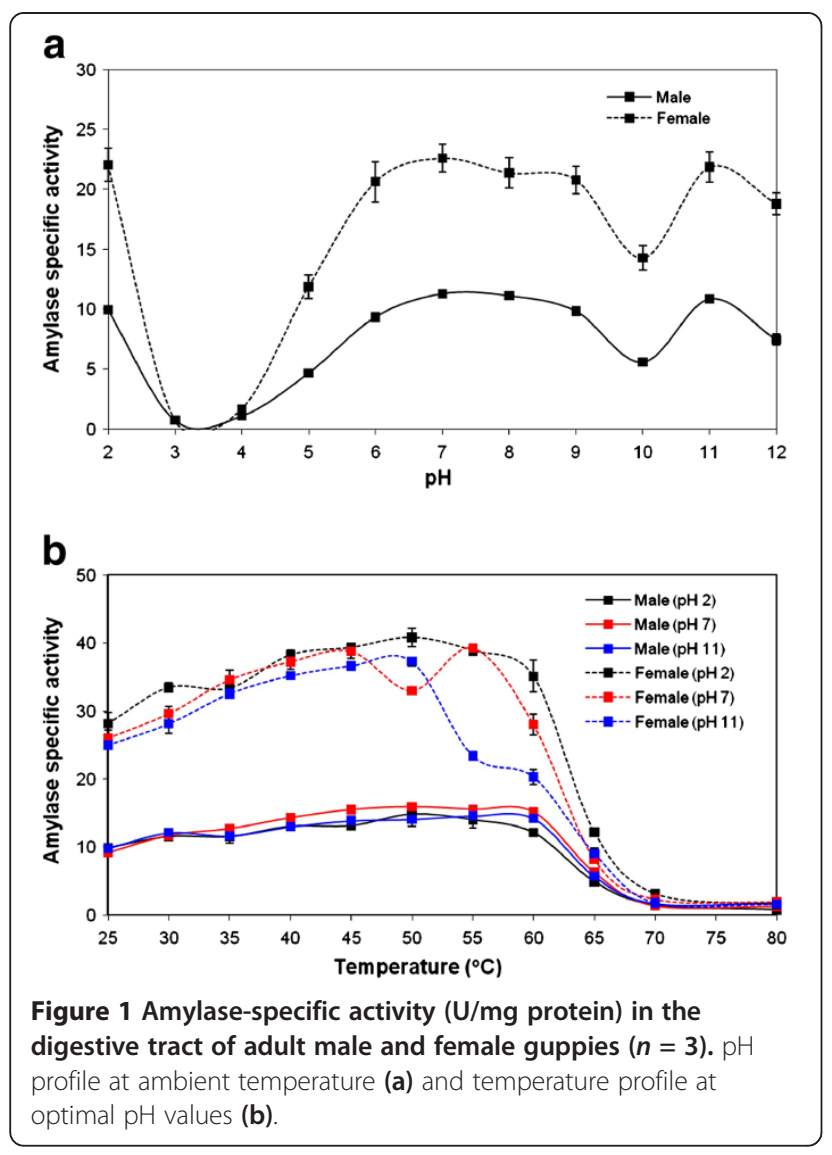

temperatures for all amylase isoforms in males were similar and in a range of $25^{\circ} \mathrm{C}$ to $60^{\circ} \mathrm{C}$ (Figure 1b), while those of females differed at $30^{\circ} \mathrm{C}$ and $40^{\circ} \mathrm{C}$ to $60^{\circ} \mathrm{C}$ for $\mathrm{pH} 2,40^{\circ} \mathrm{C}$ to $45^{\circ} \mathrm{C}$ and $55^{\circ} \mathrm{C}$ for $\mathrm{pH} 7$, and $40^{\circ} \mathrm{C}$ to $50^{\circ} \mathrm{C}$ for $\mathrm{pH} 11$. Therefore, the most suitable conditions observed for studying amylase activity in guppies, regardless of sex, were $\mathrm{pH} 2$ at $50^{\circ} \mathrm{C}$ for the acidic isoform, $\mathrm{pH} 7$ at $55^{\circ} \mathrm{C}$ for the neutral isoform, and $\mathrm{pH} 11$ at $50^{\circ} \mathrm{C}$ for the alkaline isoform.

\section{Characterization of lipase}

$\mathrm{pH}$ characteristics of lipase differed between the sexes (Figure 2a). Activity peaks of male and female lipases were mainly observed at $\mathrm{pH} 7$ with optimal temperatures at $35^{\circ} \mathrm{C}$ and $30^{\circ} \mathrm{C}$, respectively (Figure $2 \mathrm{~b}$ ). Another isoform of female lipase was found at $\mathrm{pH} 5$ (Figure 2a) with temperature optima at $25^{\circ} \mathrm{C}$ to $30^{\circ} \mathrm{C}$ and $60^{\circ} \mathrm{C}$ (Figure 2b). The most suitable conditions observed for studying lipase activity in guppies, regardless of sex, were $\mathrm{pH} 7$ and $30^{\circ} \mathrm{C}$ or $35^{\circ} \mathrm{C}$.

\section{Characterization of proteolytic enzymes}

Acidic protease was similarly detected in male and female guppies. The optimal conditions were similar and were $\mathrm{pH} 2$ (Figure 3a) and $55^{\circ} \mathrm{C}$ (Figure 3b). Alkaline proteases
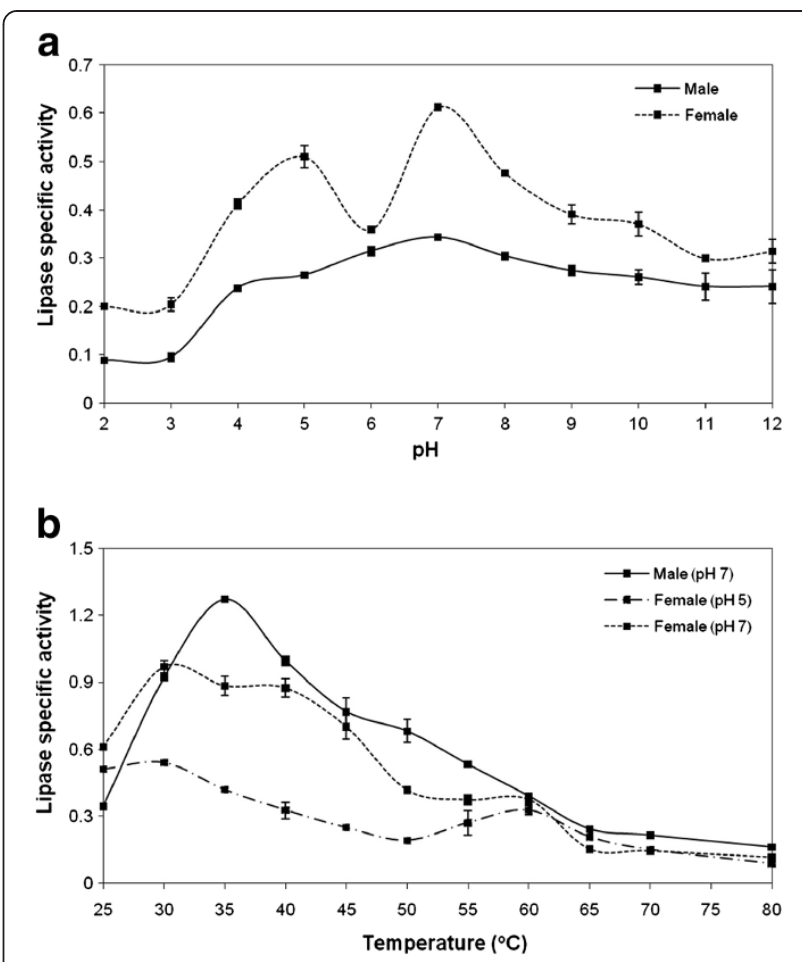

Figure 2 Lipase-specific activity (U/mg protein) in the digestive tract of adult male and female guppies $(\boldsymbol{n}=3)$. $\mathrm{pH}$ profile at ambient temperature (a) and temperature profile at optimal $\mathrm{pH}$ values (b).

were found at $\mathrm{pH} 10$ for females and at a $\mathrm{pH}$ range of 9 to 12 for males (Figure 3a), with similar maximal activities at $45^{\circ} \mathrm{C}$ (Figure $3 \mathrm{~b}$ ). Therefore, the most suitable conditions for studying total protease activity in guppies, regardless of sex, were $\mathrm{pH} 2$ and $55^{\circ} \mathrm{C}$ for acidic protease and $\mathrm{pH} 9$ at $45^{\circ} \mathrm{C}$ for alkaline protease.

Characteristic profiles of trypsin (Figure 4a,b) and chymotrypsin (Figure $5 \mathrm{a}, \mathrm{b}$ ) at various $\mathrm{pH}$ values and temperatures were similar between male and female guppies. A broad optimal $\mathrm{pH}$ of trypsin was detected at $\mathrm{pH} 8$ to 11 for females and pH 7 to 11 for males (Figure 4a). For chymotrypsin, the optimal conditions were $\mathrm{pH} 9$ to 10 (Figure 5a) and temperatures of $30^{\circ} \mathrm{C}$ to $55^{\circ} \mathrm{C}$ for females and $45^{\circ} \mathrm{C}$ to $50^{\circ} \mathrm{C}$ for males (Figure $5 \mathrm{~b}$ ). The most suitable conditions for studying trypsin and chymotrypsin activity in guppies, regardless of sex, were at $\mathrm{pH} 8$ and 9 and $50^{\circ} \mathrm{C}$, respectively.

\section{Effects of sex on specific activities of digestive enzymes}

Sex had a significant effect on specific activities of all digestive enzymes $(p<0.001$, Table 2$)$. Female guppies had higher specific activities of amylase, total protease, trypsin, and chymotrypsin than males, by approximately 2.29-, 2.65-, 3.38-, and 1.90-fold on average, respectively. On the other hand, lipase-specific activity of males was statistically higher than that of females $(p<0.001)$. For activity ratios of digestive enzymes, sex had a significant effect on the T/C 

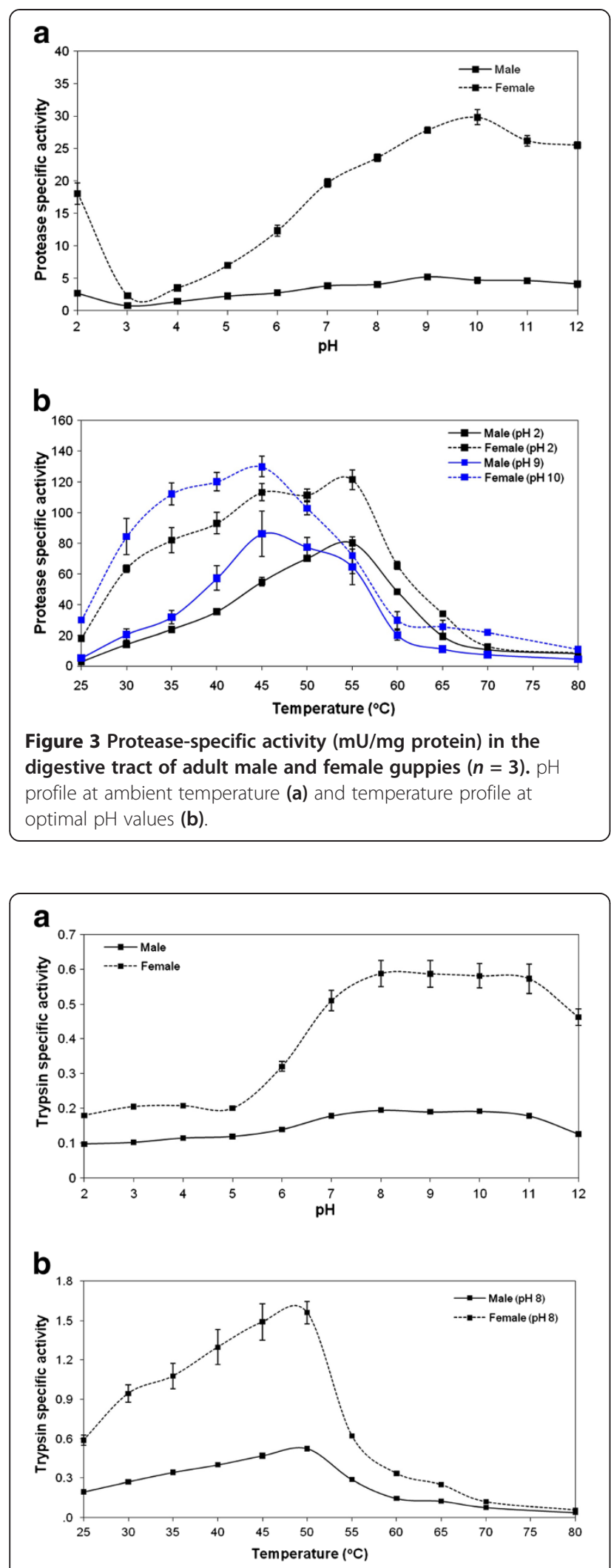

Figure 4 Trypsin-specific activity ( $\mathrm{U} / \mathrm{mg}$ protein) in the digestive tract of adult male and female guppies $(n=3)$. pH profile at ambient temperature (a) and temperature profile at optimal pH values (b).
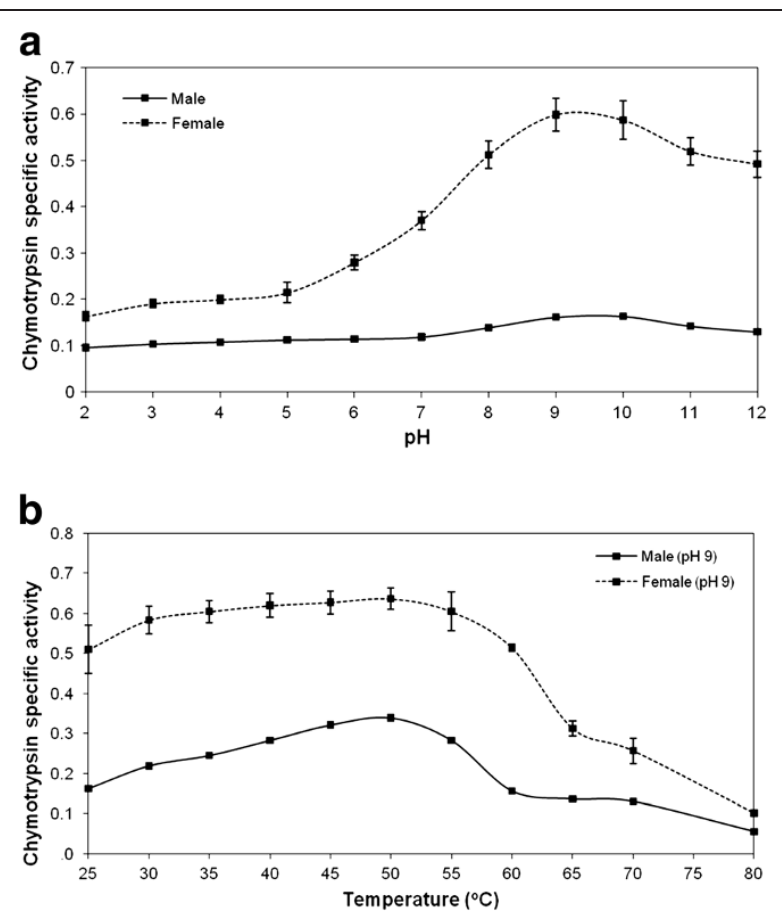

Figure 5 Chymotrypsin-specific activity (U/mg protein) in the digestive tract of adult male and female guppies $(n=3) . \mathrm{pH}$ profile at ambient temperature (a) and temperature profile at optimal $\mathrm{pH}$ values (b).

ratio $(p<0.007)$ and $\mathrm{A} / \mathrm{T}$ ratio $(p<0.04)$ as females had a higher $\mathrm{T} / \mathrm{C}$ ratio but a lower $\mathrm{A} / \mathrm{T}$ ratio compared to males.

\section{Discussion}

Growth capacity and body composition

Different growth categories of guppies influenced by sex were reported by Nakajima and Taniguchi (2002). Moreover, those of other aquatic species, such as the Australian red claw crayfish Cherax quadricarinatus (Thompson et al. 2006) and Siamese fighting fish (Thongprajukaew et al. 2013), were also observed. Generally, in nature, this phenomenon occurs in many animal species in which morphometric differences are important for sexual attraction. However, differences in weight and length between sexes were not observed, such as in powan Coregonus lavaretus (Dörücü 2000) and Opsariichthys bidens (Sui et al. 2012). An increased digestive organ weight was reported to play a potent role in increasing growth (Thongprajukaew et al. 2011). This might illustrate higher efficiencies of the gastrointestinal system for digestion, absorption, and utilization of nutrients in females than in males.

A higher lipid content was observed in female bodies compared to males (Table 2). This is in agreement with positive correlations of concurrent increases in the lipid 
content with fish size (Salam et al. 2001) and the lipid content with CF (Yousaf et al. 2011). A higher lipid content in the body of females might play a major role as a source of metabolic energy for growth and reproduction (Tocher 2003). This result is in general agreement with the effect of sex on body compositions reported in powan (Dörücü 2000), Russian sturgeon Acipenser gueldenstaedtii (Memid et al. 2006), Australian red claw crayfish (Thompson et al. 2006), and freshwater catfish Wallago attu (Yousaf et al. 2011).

\section{Characterization of digestive enzymes}

Neutral to alkaline isoforms of amylase with a $\mathrm{pH}$ range close to those in the pancreas and intestines (Chakrabarti et al. 1995) and in its natural habitat may be major enzymes for carbohydrate digestion in guppies. However, isoforms present in extreme conditions were also reported in other species, such as $\mathrm{pH} 11$ at $50^{\circ} \mathrm{C}$ in a freshwater pearl mussel (Areekijseree et al. 2004; Supannapong et al. 2008) and Siamese fighting fish (Thongprajukaew et al. 2010b). Moreover, the optimal assayed conditions for amylase activity varied with fish species, such as $\mathrm{pH} 7.0$ to 7.5 in seabream Sparus aurata and turbot Scophthalmus maximus, and $\mathrm{pH} 4.5$ to 5.0 in redfish Sebastes mentella, with an optimal temperature range of $35^{\circ} \mathrm{C}$ to $45^{\circ} \mathrm{C}$ for the three species (Munilla-Moran and Saborido-Rey 1996).

The optimal condition for neutral lipase in guppies was similarly observed in red drum larvae Sciaenops ocellatus (Lazo et al. 2007) and juvenile Siamese fighting fish (Thongprajukaew et al. 2010b), while the acidic isoform of females was close to that of purified lipase, with optimal conditions of $\mathrm{pH} 5.5$ at $35^{\circ} \mathrm{C}$ reported for Reba carp Cirrhinus reba (Islam et al. 2009). Optimal conditions for sex-specific lipase isoforms were reported by Areekijseree et al. (2002) and Thongprajukaew et al. (2010b). Other lipase isoforms with different optimal conditions were reported in many aquatic species, such as $\mathrm{pH} 8.5$ and $35^{\circ} \mathrm{C}$ to $40^{\circ} \mathrm{C}$ for juvenile red claw crayfish C. quadricarinatus (López-López et al. 2003), $\mathrm{pH} 8.0$ to 8.5 and $33^{\circ} \mathrm{C}$ to $35^{\circ} \mathrm{C}$ for grey mullet Liza parsia (Islam et al. 2008), and $\mathrm{pH} 8.5$ and $50^{\circ} \mathrm{C}$ for gilthead seabream S. aurata (Nolasco et al. 2011).

The prominence of acidic protease at $\mathrm{pH} 2$ might indicate the presence of pepsin-like enzymes in the stomach (Natalia et al. 2004). Various protease isoforms were investigated in different aquatic species (Areekijseree et al. 2004; Natalia et al. 2004; Supannapong et al. 2008; Thongprajukaew et al. 2010a). For alkaline proteases, the optimal conditions of trypsin in male and female guppies were similar to those of other fish species, such as arowana (Natalia et al. 2004), red drum S. ocellatus (Lazo et al. 2007), walleye pollock Theragra chalcogramma (Kishimura et al. 2008), and juvenile Siamese fighting fish (Thongprajukaew et al. 2010b). Similarly, the optimal condition for chymotrypsin in guppies was also found in Atlantic salmon (Rungruangsak-Torrissen 2007) and arowana (Natalia et al. 2004). The alkaline condition of trypsin and chymotrypsin is close to the $\mathrm{pH}$ in the intestinal region (Natalia et al. 2004). The suggested conditions overlap with those of alkaline proteases, indicating the importance of trypsin and chymotrypsin for protein digestion in guppies.

\section{Specific activity of digestive enzymes}

Effects of sex on digestive enzyme-specific activities in guppies are in partial agreement with the phenomena observed in the freshwater pearl mussel (Areekijseree et al. 2004) and Siamese fighting fish (Thongprajukaew et al. 2013). Significantly higher specific activities of digestive enzymes (except lipase) in females might indicate the use of more energy for growth, as illustrated by a higher BW, $\mathrm{TL}$, and CF, than in males. On the other hand, higher digestive enzyme activities might be important for sexual maturity, as observed in larger cod Gadus morhua (Rungruangsak-Torrissen et al. 2012). Moreover, findings indicate different strategies between sexes for nutrient utilization (digestion and absorption) through digestive enzymes. Significantly higher lipase-specific activity in males (in which nearly all enzymes were lower) might be attributed to it being an energy source when activities of carbohydrate- and protein-digesting enzymes are limited. The $\mathrm{T} / \mathrm{C}$ ratio showed the same trend as in weight and length values in both sexes. A higher ratio indicated faster growth and better food utilization efficiency in many fish species (Sunde et al. 2001; Rungruangsak-Torrissen et al. 2006; Rungruangsak-Torrissen 2007; Chan et al. 2008). Therefore, a higher ratio in females probably indicates better growth capacity and food utilization compared to males. For carbohydrates, the $\mathrm{A} / \mathrm{T}$ ratio was used as an effective marker to understand feeding habits (Hofer and Schiemer 1981; Gambao-Delgado et al. 2003). The significantly higher ratio in males might indicate better carbohydrate utilization or stronger omnivorous feeding habits than females. Moreover, the association of this ratio with lower weight and length might be helpful to increase agility, as observed in fast swimming behavior, which allows males to better compete for food and other resources than females, as well as for mating performance. Maintaining energy in males by reducing their size with a higher $\mathrm{A} / \mathrm{T}$ ratio is probably required. Therefore, differences in carbohydrate contents between male and female diets should be of interest.

\section{Conclusions}

Sex had a direct effect on $\mathrm{pH}$ and temperature characteristics of all digestive enzymes. The optimal conditions for studying digestive enzymes in the guppy were $\mathrm{pH} 2$ at $50^{\circ} \mathrm{C}$ for acidic amylase, $\mathrm{pH} 7$ at $50^{\circ} \mathrm{C}$ for neutral amylase, $\mathrm{pH} 11$ 
at $50^{\circ} \mathrm{C}$ for alkaline amylase, $\mathrm{pH} 7$ at $30^{\circ} \mathrm{C}$ to $35^{\circ} \mathrm{C}$ for lipase, $\mathrm{pH} 2$ at $55^{\circ} \mathrm{C}$ for acidic protease, $\mathrm{pH} 9$ at $45^{\circ} \mathrm{C}$ for alkaline protease, $\mathrm{pH} 8$ at $50^{\circ} \mathrm{C}$ for trypsin, and $\mathrm{pH} 9$ at $50^{\circ} \mathrm{C}$ for chymotrypsin, regardless of sex. Specific activities of amylase, total proteases, trypsin, chymotrypsin, and the $\mathrm{T} / \mathrm{C}$ ratio were higher in females than in males. This correlated with morphometric measurements of BW, $\mathrm{TL}, \mathrm{CF}$, and gastrointestinal weight. These findings indicate a potent effect of sex on digestive enzyme strategies for digestion, absorption, and utilization of nutrients in guppies, as indicated by alterations in specific activities of all digestive enzymes and the $\mathrm{A} / \mathrm{T}$ ratio. Therefore, sex-specific diets based on digestive enzyme activity and in vitro nutrient utilization should be of interest for this species.

\section{Competing interests}

The authors declare that they have no competing interests.

\section{Authors' contributions}

$\mathrm{KT}$ carried out the measurement of growth, analysis of body composition, and characterization of digestive enzymes and drafted the manuscript. UK participated in the design of the study, financial support, and discussion. Both authors read and approved the final manuscript.

\section{Acknowledgments}

We would like to thank the Department of Zoology, Faculty of Science, Kasetsart University, for providing an aquarium and laboratory for rearing the fish and Ms. S. Chumwaengwapee for kindly preparing the fish samples.

\section{Author details \\ ${ }^{1}$ Department of Applied Science, Faculty of Science, Prince of Songkla University, Songkhla 90112, Thailand. ${ }^{2}$ Biochemical Research Unit for Feed Utilization Assessment, Faculty of Science, Kasetsart University, Bangkok 10900, Thailand. ${ }^{3}$ Department of Zoology, Faculty of Science, Kasetsart University, Bangkok 10900, Thailand.}

Received: 30 March 2012 Accepted: 7 January 2013

Published: 30 July 2013

\section{References}

AOAC (2005) Official methods of analysis of AOAC International, 18th edn. Association of Official Analytical Chemists (AOAC), Gaithersburg

Areekijseree M, Engkagul A, Kovitvadhi U, Thongpan A, Mingmuang M, Kovitvadhi S (2002) Activity profiles at different pH and temperature of cellulases and lipases in freshwater pearl mussel: Hyriopsis (Hyriopsis) bialatus, Simpson 1900. Kasetsart J (Nat Sci) 36:399-407

Areekijseree M, Engkagul A, Kovitvadhi U, Thongpan A, Mingmuang M, Pakkong P, Rungruangsak-Torrissen K (2004) Temperature and pH characteristics of amylase and proteinase of adult freshwater pearl mussel, Hyriopsis (Hyriopsis) bialatus Simpson 1900. Aquaculture 234:575-587

Areekijseree M, Engkagul A, Kovitvadhi S, Kovitvadhi U, Thongpan A, Rungruangsak-Torrissen K (2006) Development of digestive enzymes and in vitro digestibility of different species of phytoplankton for culture of early juveniles of the freshwater pearl mussel, Hyriposis (Hyriopsis) bialatus Simpson, 1900. Invert Reprod Develop 49:255-262

Chakrabarti I, Gani MA, Chaki KK, Surand R, Misra KK (1995) Digestive enzymes in 11 freshwater teleost fish species in relation to food habit and niche segregation. Compar Biochem Physiol 112:167-177

Chan CR, Lee DL, Cheng YH, Hsieh DJY, Weng CF (2008) Feed deprivation and re-feeding on alterations of proteases in tilapia Oreochromis mossambicus. Zool Stud 47:207-214

Dörücü M (2000) Changes in the protein and lipid content of muscle, liver and ovaries in relation to Diphyllobothrium spp. (Cestoda) infection in powan (Coregonus lavaretus) from Loch Lomond. Scotland Turk J Zool 24:211-218
Gambao-Delgado J, Molina-Poveda C, Cahu C (2003) Digestive enzyme activity and food ingesta in juvenile shrimp Litopenaeus vannamei (Boone, 1931) as a function of body weight. Aquacult Res 34:1403-1411

Hofer R, Schiemer F (1981) Proteolytic activity in the digestive tract of several species of fish with different feeding habits. Oecologia 48:342-345

Islam MA, Absar N, Bhuiyan AS (2008) Isolation, purification and characterization of lipase from grey mullet (Liza parsia Hamilton, 1822). Asian J Biochem 3:243-255

Islam MA, Parveen F, Hossain K, Khatun S, Karim MR, Kim GS, Absar N, Haque MS (2009) Purification and biochemical characterization of lipase from the dorsal part of Cirrhinus reba. Thai J Agric Sci 42:71-80

Kishimura H, Klomklao S, Benjakul S, Chun BS (2008) Characteristics of trypsin from pyloric ceca of walleye pollock (Theragra chalcogramma). Food Chem 106:194-199

Lazo JP, Mendoza R, Holt GJ, Aguilera C, Arnold CR (2007) Characterization of digestive enzymes during larval development of red drum (Sciaenops ocellatus). Aquaculture 265:194-205

López-López S, Nolasco H, Vega-Villasante F (2003) Characterization of digestive gland esterase-lipase activity of juvenile redclaw crayfish Cherax quadricarinatus. Compar Biochem Physiol 135:337-347

Lowry OH, Rosebrough NJ, Farr AL, Randall RJ (1951) Protein measurement with the Folin phenol reagent. J Biol Chem 193:265-275

Memid D, Celikkale MS, Ercan E (2006) Effects of different diets on growth performance and body composition of Russian sturgeon (Acipenser gueldenstaedtii, Brandt \& Ratzenburg, 1833). J Appl Ichthyol 22:287-290

Munilla-Moran R, Saborido-Rey F (1996) Digestive enzymes in marine species II. Amylase activities in gut from seabream (Sparus aurata), turbot (Scophthalmus maximus) and redfish (Sebastes mentella). Compar Biochem Physiol 113B:827-834

Nakajima M, Taniguchi N (2002) Genetic control of growth in the guppy (Poecilia reticulata). Aquaculture 204:393-405

Natalia Y, Hashim R, Ali A, Chong A (2004) Characterization of digestive enzymes in a carnivorous ornamental fish, the Asian bony tongue Scleropages formusus (Osteoglossidae). Aquaculture 233:305-320

Nolasco H, Moyano-López F, Vega-Villasante F (2011) Partial characterization of pyloric-duodenal lipase of gilthead seabream (Sparus aurata). Fish Physiol Biochem 37:43-52

Perera E, Moyano F, Rodriguez-Viera L, Cervantes A, Martinez-Rodriguez G, Mancera JM (2010) In vitro digestion of protein sources by crude enzyme extracts of the spiny lobster Panulirus argus (Latreille, 1804) hepatopancreas with different isoenzyme patterns. Aquaculture 310:178-185

Rungruangsak-Torrissen K (2007) Digestive efficiency, growth and qualities of muscle and oocyte in Atlantic salmon (Salmo salar L.) fed on diets with krill meal as an alternative protein source. J Food Biochem 31:509-540

Rungruangsak-Torrissen K, Moss R, Andresen LH, Berg A, Waagbo R (2006) Different expressions of trypsin and chymotrypsin in relation to growth in Atlantic salmon (Salmo salar L). Fish Physiol Biochem 32:7-23

Rungruangsak-Torrissen K, Thongprajukaew K, Sansuwan K, Thapthimdaeng P, Kovitvadhi U, Seetaha S, Choowongkomon K, Beck IM, Arnøy OO (2012) Ecological effects on food utilization, trypsin isozymes, and performance qualities of growth and maturation in northeast Arctic cod (Gadus morhua L.). Open Fish Sci J 5:44-56

Salam A, Ali M, Anas M (2001) Body composition of Oreochromis nilotica in relation to body size and condition factor. Pak J Res Sci 12:19-23

Sui XY, Yan YZ, Chen YF (2012) Age, growth, and reproduction of Opsariichthys bidens (Cyprinidae) from the Qingyi River at Huangshan Mountain, China. Zool Stud 51:476-483

Sunde J, Taranger GL, Rungruangsak-Torrissen K (2001) Digestive protease activities and free amino acids in white muscle as indicators for feed conversion efficiency and growth rate in Atlantic salmon (Salmo salar L.). Fish Physiol Biochem 25:335-345

Supannapong P, Pimsalee T, A-komol T, Engkagul A, Kovitvadhi U, Kovitvadhi S, Rungruangsak-Torrissen K (2008) Digestive enzymes and in vitro digestibility of different species of phytoplankton for culture of the freshwater pearl mussel, Hyriopsis (Hyriopsis) bialatus. Aquacult Int 16:437-453

Thompson KR, Metts LS, Muzinic LA, Dasgupta S, Webster CD (2006) Effects of feeding practical diets containing different protein levels, with or without fish meal, on growth, survival, body composition and processing traits of male and female Australian red claw crayfish (Cherax quadricarinatus) grown in ponds. Aquacult Nutr 12:227-238

Thongprajukaew K, Kovitvadhi U, Engkagul A, Rungruangsak-Torrissen K (2010a) Characterization and expression levels of protease enzymes at different developmental stages of Siamese fighting fish (Betta splendens Regan, 1910). Kasetsart J (Nat Sci) 44:411-423 
Thongprajukaew K, Kovitvadhi U, Engkagul A, Rungruangsak-Torrissen K (2010b) Temperature and $\mathrm{pH}$ characteristics of amylase and lipase at different developmental stages of Siamese fighting fish (Betta splendens Regan, 1910). Kasetsart J (Nat Sci) 44:210-219

Thongprajukaew K, Kovitvadhi U, Kovitvadhi S, Somsueb P, RungruangsakTorrissen K (2011) Effects of different modified diets on growth, digestive enzyme activities and muscle compositions in juvenile Siamese fighting fish (Betta splendens Regan, 1910). Aquaculture 322-323:1-9

Thongprajukaew K, Kovitvadhi U, Kovitvadhi S, Engkagul A, RungruangsakTorrissen K (2013) Evaluation of growth performance and nutritional quality of diets using enzymatic markers and in vitro digestibility in Siamese fighting fish (Betta splendens Regan, 1910). Afr J Biotechnol 12(14):1689-1702

Tocher DR (2003) Metabolism and functions of lipid and fatty acids in teleost fish. Rev Fish Sci 11:107-184

Winkler UK, Stuckmann M (1979) Glycogen, hyaluronate and some other polysaccharides greatly enhance the formation of exolipase by Serratia marcescens. J Bacteriol 138:663-670

Xie F, Ai Q, Mai K, Xu W, Ma H (2011) The optimal feeding frequency of large yellow croaker (Pseudosciaena crocea, Richardson) larvae. Aquaculture 311:162-167

Yousaf M, Salam A, Naeem M (2011) Body composition of freshwater Wallago attu in relation to body size, condition factor and sex from southern Punjab, Pakistan. Afr J Biotechnol 16:4265-4268

doi:10.1186/1810-522X-52-3

Cite this article as: Thongprajukaew and Kovitvadhi: Effects of sex on characteristics and expression levels of digestive enzymes in the adult guppy Poecilia reticulata. Zoological Studies 2013 52:3.

\section{Submit your manuscript to a SpringerOpen ${ }^{\circ}$ journal and benefit from:}

- Convenient online submission

- Rigorous peer review

- Immediate publication on acceptance

- Open access: articles freely available online

- High visibility within the field

- Retaining the copyright to your article

Submit your next manuscript at $\gg$ springeropen.com 